low-pressure lamp emitting mainly at $185 \mathrm{~m} \mu$ and $254 \mathrm{~m} \mu$. Both lamps have synthetic quartz envelopes. The reactor will undoubtedly be valuable for physical chemistry research as well as biological work, and the cone and socket arrangement makes it suitable for use also in the study of reactions in the gaseous phase. By circulating oxygen or air around the lamp it could, of course, be used as an ozone generator.

\section{Alaskan Mammals}

A USEFul brochure entitled The Distribution of Alaskan Mammals, by R. H. Manville and S. P. Young, has been published by the U.S. Bureau of Sport Fisheries and Wildlife (United States Department of the Interior: Fish and Wildlife Service. Bureau of Sport Fisheries and Wildlife. Circular No. 211. Pp. iv + 74. Washington, D.C.: Government Printing Office, 1965. 50 cents). A map showing the distribution within the State is given for each species, together with notes on the complete range of the species, its habitat, the races found in Alaska, and on related species. A black-and-white drawing illustrates each species competently; the scraper-board figures greatly exceed in effect those in pen and ink; that of the porcupine, Erethizon dorsatum, and especially that of the bearded seal, Erignathus barbatus, are splendid. The Cetacea are not treated in detail but are given an overall note and a list of recorded species. The introductory matter includes a short article on the distribution of Alaskan mammals, another on the mammalian fauna in general, and a list of 102 species in systematic order. The rapid opening up of the State to travel and tourism, and the establishment of the University and other centres of scientific activity, give great opportunities for an intensified study of Alaskan mammals, for which this publication will provide a valuable foundation.

\section{Conservation of the Bee Orchis}

RARE bee orchises (Ophrys apifera) were discovered on the Dykes of the Avebury Stone Circle, Wiltshire, during July 1965, by one of the custodians of the Office of Works, Mr. Hulbert, and the curator of the Museum, Mr. H. M. V. Young, who immediately alerted the headmistress of the parochial school, and her assistants and caretaker, all keon naturalists. The teachers found that the plants were flowering in the same spot in which they had appeared eight years ago, widely scattered over an area of 300 square yards. Seventeen were counted in bloom, and investigation showed that there had been at least twentytwo. Of the five known casualties, two had been picked by local adults and three were found discarded, probably by a coach party who may have carried some others away. Only nine Avebury people knew of the bee orchids and they agreed to conserve them if possible. Photographs were taken and further counts were made by the hoadmistress, who thinks one more was picked during the next week. Fourteen days from the first discovery, onty one in the fruiting stage was seen, and this had well-formed seed pods. Bad weather and long grass prevented a prolonged search, but it is hoped that a few more remained to set seed. This small effort at conservation was prompted by a lecture on the Nature Conservancy Trust given by the Countess of Radnor to the Wilt. shire Rural Studies Association. Further information can be obtained from Miss E. Dampier-Child, School House, Avebury, Wiltshire.

\section{The International Commission on Radiological Pro- tection}

THE following have been elected officers and members of the International Commission on Radiological Protection for the period 1965-69: Chairman, Dr. E. E. Pochin (United Kingdom); Vice-Chairman, Dr. C. (. Stewart (Canada); Council, Prof. L. Bugnard (France),
Prof. O. Hug (Germany), Dr. H. Jammet (France), Prof. A. A. Letavet (U.S.S.R.), Prof. B. Lindell (Sweden), Dr. J. F. Loutit (United Kingdom), Dr. K. Z. Morgan (United States), Dr. H. B. Newcombe (Caneda), Ir. C. C. Powell (United States), Dr. L. S. Taylor (United States) and Prof. B. Windeyer (United Kingdom); Chairman Emeritus, Prof. R. M. Sievert (Sweden); Scientific Secretary, Dr. F. D. Sowby (Canada). The Commission's seeretariat is at Clifton Avenue, Sutton, Surrey, England.

\section{The National Institute of Sciences of India}

THE following have been elected members of the Council of the National Institute of Sciences of India for 1966: President, Dr. V. R. Khanolkar; Vice-Presidents, Dr. Atma Ram and Dr. S. Bhagavantam; Treasurer, Prof. R. C. Majumdar; Foreign Secretary, Prof. B. R. Seshachar; Secretaries, Prof. F. C. Auluck and Dr. N. K. Panjkkar; Editor of Publications, Prof. P. Maheshwari; Members of Council, Sri S. Basu, Prof. P. N. Bhaduri, Prof. P. L. Bhatnagar, Prof. R. N. Chakravarti, Prof. N. R. Dhar, Dr. K. R. Dixit, Dr. T. R. Govindachari, Dr. A. G. Jhingran, Dr. M. S. Krishnan, Prof. T. S. Mahabale, Prof. K. C. Mukherji, Dr. K. R. Nair, Dr. B. P. Pal, Dr. R. K. Pal, Prof. T. R. Seshadri, Prof. S. M. Sircar, Prof. J. Venkateswarlu, Prof. P. N. Wahi and Dr. H. J. Bhabha (past president, exi-officio).

The Year Book of the National Institute of Sciences of India, 1964 (Pp. 133. New Delhi: National Institute of Sciences of India, 1965), includes, besides an account of the foundation of the Institute and the calendar for 1964, lists of the Council senior office staff, of Fellows, of the members of committees, and of representatives on other organizations. The rules and regulations of the Institute are also included as well as lists of the Institute's medals, lectures and publications.

\section{University and College News:}

Cambridge

THe following have been elected to fellowshipe at Churchill College: Title A, Dr. I. T. Drummond (mathematics); Title $E$, Dr. B. B. Roberts.

Edinburgh

THE following locturers have been appointed: J. H. Penman (animal health); Dr. J. S. McKinley (biochemistry).

\section{University College of Swansea}

THE following lecturers have boen appointed: Dr. R. C. V. Macario and D. Bell (electrical engineering).

\section{Announcements}

A SyMposium on "CNS-Drugg" will be held at tho Regional Research Laboratory, Hyderabad, during January $24-30$. Further information can be obtained from Dr. P. B. Sattur, Rogional Research Laboratory, Hyderabad 9.

A symposium on "Regulation of the Antibody Response" will be held in Toronto during January 20-22. Further information can be obtained from Dr. B. Cinader, Subdivision of Immunochemistry, Division of Biological Research, O.C.I., 500 Sherbourne Street, Toronto 5.

A ONE-DAY symposium on "Engineering the World's Airport Passenger Terminals" will be hold at the Institution of Civil Engineers, London, on January 25. Further information can bo obtained from the Secretary, Institution of Civil Engineors, Great George Street, London, S.W.1.

A ONE-DAY symposium on "Food Safety", organized by the Luton College of Technology and the Institute of Biology, will be held in the College on January 22. Further information can be obtained from Dr. F. C. Webber, Luton College of Technology, Park Square, Luton, Bedfordshire. 